\section{NEW FORENSIC SCIENCE LABORATORY}

$\mathrm{T}$

HE new Homo Office Laboratory at Preston was opened on July 27 by Mr. A. L. Dixon, Assistant Under-Secretary of State of the Home Department. The staff and equipment are provided by the Home Office, which also meets the running costs during the initial period. The accommodation has been provided by the Lancashire Standing Joint Committee. The Laboratory will serve the NorthWestern Area, which includes Lancashire, Westmorland and Cumberland and Cheshire.

The new Laboratory is conveniently arranged on one floor. The administrative offices are arranged in a central hall, from which the various laboratory sections are readily accessible. Tho Laboratory is furnished with modern equipment for carrying out chemical (including microchemical), physical and biological investigations. Thero is also a fully equipped photographic section, including apparatus for microphotographic work.

This is tho fourth laboratory to bo established, others being at Birmingham, Cardiff and Nottingham. Each laboratory is equipped to cover the range of work which would satisfy all general requirements, but it would bo impossible to equip each laboratory to cover every possible case. This aspect is, however, largely met by giving each laboratory some special section, and in the case of the laboratory at Preston, the provision for dealing with chemistry problems is made as complete as is reasonably possible. Thus by reciprocal arrangements botween these forensic scienco laboratories (and in special cases certain Government laboratories) it is possible to cover practically every phase of the work.

The principal function of the Laboratory is to give scientific assistance in the detection of crime to the police in the area served by the Laboratory. The police, however, have no control over the work which goes on in the Laboratory; that work is solely under the control of the Director. He has only one thing to do-to find out what the various specimens submitted (and in some cases his observations at the scene of crime) reveal from the scientific point of view. It may well be that the results completely negative the police case and favour the defence. That is no concern of the Director; he will state his findings, which will bo available to both sides.

In addition to the purely laboratory work, it is part of the work of the Director to organize courses of instruction which are available to the various detective forces in the area. This course includes the careful collection and preservation of materials to be submitted to the Laboratory for examination.

The Laboratory, therefore, includes a museum in which exhibits from various typical crimes will bo collected and used for instructional purposes. Although the new buildings have only been recently opened, the Laboratory was first started in September 1938 in temporary premises with Dr. J. B. Firth as director, and in this interim period on no less than 140 occasions have materials been submitted for examination and some 556 exhibits examined. These figures themselves will indicate in some measure that the new Laboratory with its more complete staff and equipment will be a great asset to the area which it is designed to serve.

J. B. F.

\section{SCIENCE NEWS A CENTURY AGO}

\section{Drainage of Lands by Steam Power}

TuE Gentleman's Magazine of August 1839 contains the following information: "The drainage of land by steam power has been extensively adopted in the fens of Iincolnshire, Cambridgeshire and Bedfordshire, and with immense advantage. A steam engino of ten horse-power has been found sufficient to drain a district comprising a thousand acres of land, and the water can always bo kept down to any given distance below the plants. If the rainfall is excessive. the water is thrown off by the engine; if the weather is dry, the sluices can bo opened and tho water let in from the river. The engines are required to work four months in the twelve, at intervals varying with the season; where the districts are large, the expense of drainage by steam power is about $2 s .6 d$. per acre."

\section{The Travels of J. D. Forbes in 1839}

EArLy in August 1839, J. D. Forbes returned to Edinburgh after spending three months in south-east France, Switzerland and Italy. On his way south ho visited Paris, meeting Arago, Cauchy, Elie de Beaumont and Niepco, and was particularly interested in Daguerro's pictures. He then travelled south by way of Dijon, Chalons and Lyons on the way to the department of Ardêche. From Montpezat he wrote of the district that "in a geological sense it is interesting in the highest degree, and I have four or five craters, just as well-defined and as recent-looking as Vesuvius, within a day's walk. . . . There are deep granito valleys divided by serrated mountains, through which here and there a cindery volcano thrusts his roasted head, while the valleys are clothed with chestnut and mulberry trees in the most ex. quisite manner". On July 5 he made an investigation of a meteorite which fell on June 15, 1821, "one of the very few which have fallen so near to intellegent spectators as actually to endanger their lives".

From the volcanoes of Auvergne, Forbes proceeded to Marseilles and then turned north to exploro the little-frequented valleys around Monte Viso on the borders of Piedmont. He visited the village of St. Veran, $6591 \mathrm{ft}$. above sea-level, "the highest in Europe, except that of Soglio in the Tyrol", and attempted the circuit of Monte Viso. From these excursions ho returned to Grenoble, and then having visited a brother at Geneva he travelled through some of the unknown valleys to the south, and then by way of Cogne and Ponto he reached Turin. On August 2 he visited the astronomer Plana, "overwhelmed with official engagements", and on the following day the geologist Sismondi.

\section{Kent Zoological and Botanical Gardens}

ON Thursday, August 8, 1839, "a party of citizens visited this delightful spot in a steamer, when about 650 gentlemen and ladies were regaled with a dejeuner, under a spacious pavilion erected in the gardens for the occasion. . . The gardens are those at Rosher. ville near Gravesend. This piece of land, or the greater portion of it, consisting of seventeen acres, was taken into its hands by a company of gentlemen more than a year since, and by then it was made the object of a most extensive plan for the securing of its natural beauties and adding to it new and unusual attractions. - . Clever use has been made of the excavation into the chalk cliffs . . a further advance in the valley conducts to the botanical beds whero it is 
intended to cultivate the rarest plants and flowers which the climate will allow. . . . Immediately next the perpendicular cliffs of these tro divisions arrangements are to be mado and are now in progress for the reception of wild beasts, birds and sea-fowl, etc." (Mechanic and Chemist.)

\section{Thomas Tredgold}

Tredgold, one of the founders of engineering theory and the author of the well-known definition of civil engineering embodied in the charter of the Institution of Civil Engineers, died in January 1829 at forty years of age, worn out by his exertions.

On August 10,1839 , the Mechanics' Magazine said, "To architects, engineers and persons concerned in any department of building the name of Tredgold must not only bo familiar, but likewise respected and valued, and it is presumed not less so by many individuals in the higher walks of life. To all such it must bo a matter of painful interest to bo informed that the family of such a highly gifted man and martyr to science, consisting of an aged mother, two daughters in oxtremely delicato health, and a son of about thirteen years of age, are in very dependent circumstances. His friends have long cherished the hope that long before this time-for it is now ten years sinco his death-their situation might have attracted the favourable notice of government; but as this has not been the case, Mr. Habershon, one of his early friends and his biographer, with John Donkin, Esq., his joint executor, have commenced a subscription in furtherance of this laudable object."

\section{Discovery of a Mammoth's Tusk}

Trif issue of the Athenceum of August 10, 1839, states that at a meeting of the Bristol Philosophical Society "Dr. Fairbrother exhibited the tusk of a mammoth which had been found on the line of the Great Western Railway, near the spot where the city boundary crosses the line ... in the lower part of a bed of gravel which reposes upon red sandy and marly bzds, forming a part of the 'New Red Sandstone' formation. Its length is about $5 \frac{1}{2}$ feet, its circumference varying from 21 to 10 inches. It is curved in a form nearly circular and occupies an are of about 140 degrees. Mr. Stutchbury supposes it to be a part only of the original tusk, which was probably 9 feet in length."

\section{APPOINTMENTS VACANT}

Applicstioss are invited for the following appointments, on or before the dates mentioned:

Assistaxt II under the Ordnance Board, Woolwich-Secretary (S.E.3), Iinistry of Supply, The Adelphi, W.C.2 (quoting Appts. 01/S.E.3) (August 11).

AsSISTANT I at Air Ministry Headquarters--Under-Secretary of State, Air Ministry (S2A/BS019), Berkeley Square House, Berkeley Square, W.1 (quoting Ref. No. B.2.9) (August 11)

TEMPORARY Assistasts Grade III (Male) in the Meteorologica Office-Under Secretary of State, S.2.B.(Met.), Air Ministry, Adastral House, Kingsway, Wi.c.2 (August 14).

ASSISTANT LECTCRER IN ORGANIC CHEMISTRY-Registrar, UniverASSISTANT LECTCRER IN OROANIC CHEMISTRY-
sity College of the South-West, Exeter (August 19).

CHIE ASSISTANT in the Chemistry Department-The Secretary, Robert Gordon's Technical College, Aberdecn.(August 26).

LIBRARIAx in the University of Cape Town--Sccretary, Office of the High Commissioner for the Union of South Africa, Trafalgar Square, W.C.2 (September 8).

Ustrersity Chair of Cheystray at the Royal Cancer Hospital (Free)-Academic Registrar, University of London, Scuate House, W.C.1 (September 15)

Assistast Exgiveer for the Malayan Public Works ServiceCrom Agents for the Colonies, 4 Millbank, S.W.I (quoting M/5731).

\section{REPORTS AND OTHER PUBLICATIONS \\ (not included in the monthly Books Supplement)}

Great Britain and Ireland

University of Bristol. The Annual Report of the Agricultural and Horticultural Research Station (the National Fruit and Cider Institute) Long Ashton, Bristol, 1933. Pp. $295+9$ plates. (Bristol: The Uni versity.)

Mines Department. Seventeenth Annual Report of the Safety in Jines Research Board, including a Report of Matters dealt with by the Health Advisory Committee, 1933. Pp. Iv +123+10 plates. (London: H.Jf. Stationery Office.) 2s. net. [247 Nutrition of Children. By Eudie Williams. (Cardiff: Priory Press, Ltd.) 10s. per 100

The Bronze Axe: the Seven Stages of its Development in Britain (2000-500 B.c.). By w. Foot Walker. (Booklet No. 3.) I'p. 39. (IIull Muscum Aid".") 18. 6d.

Air Ministry: Aeronantical Research Committee: Reports and IIemoranda. No. $1843(3651)$ : Experiments on the Teports and the Laminar Boundary Layer on a Flat Plate. By A. A. IIall and G. S. I Hislop. Pp. 27. 4s. net. No. $1855(3675)$ : Experiments on G. S. Irislop. Pp. 27. 4s. net. No. $1855(3675)$ : Expariments on A. F. Brown. Pp. 4. 9d. net. No. 1857 (3552): A Possible Form of High Speed Water Channel. By A. Mr. Binnie. Pp. 9. 18. Gd. net. (London: Ir.y. Stationery office.)

[267

Scientiflc Proceedings of the Royal Dublin Society. Vol. 20 (N.S.), No. 15 : Leaf Jovement on Rclease of Sap Tension. By Prof. Henry $H$ Dixon and J. S. Barlcc. I'p. 175-150+plate 4. 18.6d. Yol. 22 (N.S.) No. 16: Studies in Peat, Part 6: The "Water Phase" in Azcotropic Extraction Solvents, By J. Reilly and D. F. Felly, Pp. 181-186. Gd Yol. 22 ( ..S.), No. 17: Studies in Peat, Part 7 : Water Distribution in Peat Wax Azeotroplc Extraction Solvents. By J. Relly, D. F Kelly, J. Duffy and E. Coughlan. Pp. 187-194. 6d. (Dublin: Hodges,
Figgis and Co., Ltd. ; London: Williams and Norgate, Itd.) [277

\section{Other Countries}

Ceylon. Part 4: Education, Science and Art (D). Administration Reprt of the Acting Director of Agriculture for 1937. By E. Rodrigo. Pp. D93. (Colombo: Government Record Office.) 1 rupee. [247 Indian Forest Records (New Series.) Silviculture, Vol. 3, No. 6 : a Study of the Soils in the Hill Aress of Kashmir : an Investigation of Soil Protles under Deodar, Blue Pine, Silver Fir and Chir. By Dr.

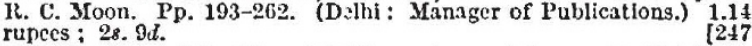

Publications of the Nizamiah Observatory. Astrograplic Catalogue 1900.0, Ifyderabad Section (Part 3), D*c. $+35^{\circ}$ to $+40^{\circ}$, from Photographs taken and measured at the Nizamial ${ }_{1}$ observatory, Hyderabad, under the direction of T. 1'. Bhaskaran. Fol. 11: Beasures of Rectangular Co-ordinates and Diameters of 50,907 Star-Images on plates with Centres in Dec. $+37^{\circ}$. Pp. xxvili +193 . (Begumpet: Nizamiah Observatory.) 15 rupees; 208 . net.

Annales scientiflques de l'Université de Jassy. Premilre partie (Mathématiques, physique, chimie), Tome 25, Annéc 1039. 1. Pp. 310, Fascicule 2. Pp. 341-693. Seconde partie (Sciences naturelies), Tome 25, Anné 1939. Fascicule 1. Pp. 336. Fascicule 2.

Arin through the New Building of Jellon Institute. Second A Trip through the New Building of Jellon Institute. Second
edition. Pp. vi+20. (Pittsburgh, Pa.: Mellon Institute.) U.S. Department of the Interior: Office of Education. Know your School, Leaflet No. 51 : Know your School Child. By IIary Dabney Davis. P'p. Hil + 18. (Washington, D.C.: Government Printing Office.)
5 cents.
[257]

Cawthron Institute, Nelson, New Zealand. Annual Report, 1938. I'p. 35. (Nelson: Cawthron Institute.)

Advisory Committec on Education. Staff Study No 1: Elucation Advisory Committec on Education. Staff Study No 1 : Elucation
in the Forty-cight States. 13y Payson Smith, Frank w. Wriglit and in the Forty-cight States. I3y Payson Smith, Frank W. Wright and Associates, Pp. $x v+193$. (Washington, D.C.: Government Printing
Officc.) 30 cents.

New York Academy of Sciences. Scientille Survey of Porto Rico and the Virgin Islands. Yol. 14, Part 3 : Insects of Porto Rico and the Virgin Islands- Hemiptera-Heteroptera (excepting the Miridae and Corixidae). By Harry Gardner Barber. Pp. 26t-412. (New
York: New York Academy of Sciences.) 2 dollars.
[257 Classifled List of Smithsonian Publications available for Distribution, June 26, 1939. Compiled by Helen IIunroe. (Publication 3544.)

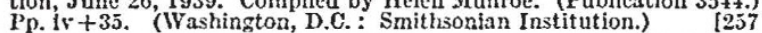
Brooklyn Botanic Garden Record. Vol. 23, No. 3: The Rose Garden of the Brooklyn Botanic Garden. Bv Iontague Free. (Guide No. 9.) of the Brooklyn Botanic Garden. By Jontagne Free. (Guide No. 9.)
Pp. 159-216. (Brooklyn, N.Y.: Brooklyn Institute of Arts and Pp. 159-216. (Brooklyn, X.Y.: Brooklyn Institute of Arts and
[257 U.S. Department of the Interior: Geological Survey. WaterSupply Paper 796-G : IIajor Texas Floods of 1935. By Tate Dalrymple and others: Pp. v+223-290+ plates 5t-62. 15 cents. Water-Stuppls Paper 8.3: Surface Water Supply of the United States, 1937. Part 3 : Ohio River Basin. Pp. vii +375 . 40 cents. Water-Supply Paper 812 : Floods in the Canadian and Pecos River Basins of New Mexico, May and June 19:37; with Summary of Flood Discharges in New Mexico. By Tate Dulrymple and others. Pp. iv $+63+9$ plates. 20 cents.

New York Zoological Society. Report of the Director of the New York Zoological Societs. Weport of the Dirctor of the League of Nations: Information Section: Fssential Facts about the League of Nations. Tenth edition, revised. Pp. $350+4$ plates. (Geneva: League of Tations; London: George Allen and Unwin,
Ltd.) 18. 